Article

\title{
Phenolic Compounds of Soybean Seeds from Two European Countries and Their Antioxidant Properties
}

\author{
Angelika Król-Grzymała ${ }^{1, * \mathbb{D}}$ and Ryszard Amarowicz ${ }^{2}$ (D) \\ 1 Department of Biology and Biotechnology, Chair of Biochemistry, University of Warmia and Mazury, \\ 10-748 Olsztyn, Poland \\ 2 Division of Food Science, Institute of Animal Reproduction and Food Research of the Polish Academy \\ of Science, 10-748 Olsztyn, Poland; amaro@pan.olsztyn.pl \\ * Correspondence: angelika.krol@uwm.edu.pl; Tel.: +48-8952-320-35
}

Academic Editor: Anna Andolfi

Received: 18 March 2020; Accepted: 26 April 2020; Published: 29 April 2020

\begin{abstract}
There is only a small acreage of planted soybeans in northern Europe, as the global production of this crop is mainly dictated by the warmer temperatures needed for bountiful yields. The defense response of soybean plants to a cold climate entails the secretion of specific compounds which help mitigate oxidative stress, i.e., antioxidants, including phenolic compounds. The objective of this study was to examine differences in the concentrations of phenolic compounds, their antioxidant properties, and the concentration of key isoflavones (namely genistein, daidzein, malonyl daidzein, malonyl genistein, and daidzin) in the seeds of six soybean cultivars from two different regions of Europe, namely Poland and France. The total phenolic contents, isoflavone levels, and in vitro antioxidant capacities of soybean seeds from most of the investigated cultivars of northeast Europe were found to be greater than those from southwest Europe. The phenolic compounds of seed extracts are primarily responsible for the free-radical scavenging of soybeans. Factors regulating the production of phenolic compounds in the seeds have not been thoroughly elucidated. Hence, the results presented in this paper can be useful in the selection of soybean cultivars with higher levels of seed phenolics, because of their beneficial impact on human health and on the soybean's defense mechanism against plant stresses.
\end{abstract}

Keywords: soybean; seeds; phenolic compounds; isoflavones; antioxinants

\section{Introduction}

With respect to the carbon endoskeleton, phenolic compounds can be divided into four basic groups. One group consists of hydroxybenzoic acids (C6-C1), the second comprises phenylpropionic acids (C6-C3), the third is made up of flavonoids (including isoflavones) based on the carbon skeleton type $\mathrm{C} 6-\mathrm{C} 3-\mathrm{C} 6$, and the final group is phenolics with the carbon skeleton $(\mathrm{C} 15)_{n}$, which forms tannins $[1,2]$.

Isoflavones can be found in all plant parts, but their greatest concentration is in the seeds. Currently, 12 isoflavones have been identified in soybean seeds [3]. The most commonly reported soybean isoflavones in literature are two aglycones (daidzein, genistein), their glucosides (daidzin, genistein), and their malonylglysosides (malonyldaidzein, malonylgenistein) [4]. Since the 1990s, there has been an increasing interest in the bioactive properties of isoflavones. Many studies have shown that phenolic compounds, including isoflavones, bestow marked antioxidant properties, and that they are an important component of the plant's non-enzymatic defense system towards abiotic and biotic stresses [5], e.g., thermal stress [6] or pathogens [3]. Furthermore, isoflavones have a positive effect on human health. Soybean isoflavones have effectively reduced lipid peroxidation in low density 
lipoprotein (LDL) cholesterol molecules, significantly reduced the risk of type II diabetes [7], and may also possess anti-cancer efficacy [8].

Under stress conditions, phenolic compounds are often synthesized in plants at elevated quantities. Studies have implied the induction of their synthesis by stress factors, which belong to biotic impacts, such as pathogens or lesions, and abiotic ones, like UV radiation, oxidative stress, water deficiency, and low temperatures [9-12]. Phenolic compounds can act as antioxidants, helping to support the endogenous enzymatic antioxidant systems in cells and to scavenge free radicals such as reactive oxygen species [13-15]. Different plant varieties often have varying tolerance to adverse environmental conditions. Phenolic compounds that are an important element of the plant's defense system may have roles as biochemical markers of stress responses [16].

As an illustration, take into account the cold Polish climate and the important role of phenolic compounds in the protection of plants against various stresses. A possible solution is to plant cultivars that can better adapt to the unfavorable climate; in other words, which are less sensitive to chill stress. The purpose of this study was to compare the compositional profile and quantities of isoflavones found in soybean seeds from cultivars bred in Poland and France (the later grown in a much warmer climate) as well as reporting the antioxidant properties of the phenolic extracts so obtained from these seeds.

Common soybean (Glycine max L. Merr.) is an annual plant from Fabaceae (the bean family). Soybean seeds are a valuable source of nutrients: they contain roughly $40 \%$ protein, with their amino acid composition beneficial to human health, $20 \%$ cholesterol-free oil, including a high percentage of lipids rich in unsaturated fatty acids, and 33\% carbohydrates as well as important macrominerals such as calcium and iron [17]. Soybean seeds also comprise functional components or bioactives, like oligosaccharides, phytosterols, anthocyanins, phytic acid, saponins, and isoflavones [18]. According to FOA statistics, 241 million tons of soybean seeds were produced worldwide in 2012. In northern Europe, however, soybeans are grown on a relatively small scale due to the cooler climate. The most favorable conditions for soybean cultivation in Europe are in the southeast, where the climate is temperate, and in the southwest, where the growing season for crops is longest [19].

It is common knowledge that interactions of plants with their environment will impact the biosynthesis of various secondary plant metabolites. Several years ago, phenolic compounds, an element of the secondary metabolism, were thought to be just metabolic by-products and practically worthless [20]. More recent studies have now demonstrated that phenolics play a significant signaling and protective role in plants. Furthermore, they can have a broad influence on the health of humans and animals eating these pulses [21].

\section{Results}

\subsection{Total Phenolics Content (TPC)}

The TPC results are shown in Table 1. The analysis revealed TPC values in seed extracts ranging from 10.3 to $13.7 \mathrm{mg} / \mathrm{g}$ of extract. Among the analyzed cultivars, cv. Mazowia possessed the highest content of phenolic compounds ( $13.07 \mathrm{mg} / \mathrm{g}$ of extract). Lower concentrations of phenolics were found in the cultivars Satina ( $12.5 \mathrm{mg} / \mathrm{g}$ of extract), Augusta ( $12.4 \mathrm{mg} / \mathrm{g}$ of extract), and Progres (12.04 mg/g of extract). The seed extract from Polish cv. Aldana contained even less phenolics ( $11.7 \mathrm{mg} / \mathrm{g}$ extract). Of all cultivars examined, the lowest TPC was determined in the French variety Isidor $(10.3 \mathrm{mg} / \mathrm{g}$ of extract). In this work, the TPCs of all analyzed seeds were calculated per $100 \mathrm{~g}$ of fresh weight (FW) and dry weight (DW) of the seeds, as well as per seed (Table 1). 
Table 1. The total phenolics contents (TPCs) in soybean seeds.

\begin{tabular}{cccc}
\hline Variety & $\mathbf{m g} / \mathbf{g}$ Extract & $\mathbf{m g} / \mathbf{1 0 0 g} \mathbf{F W}$ & $\mathbf{m g} / \mathbf{1 0 0 g} \mathbf{D W}$ \\
\hline Aldana & $11.7 \pm 0.2^{\mathrm{c}}$ & $2.13 \pm 0.04^{\mathrm{b}, \mathrm{c}}$ & $2.32 \pm 0.03^{\mathrm{b}}$ \\
Augusta & $12.4 \pm 0.1^{\mathrm{b}}$ & $2.13 \pm 0.02^{\mathrm{b}}$ & $2.26 \pm 0.02^{\mathrm{c}}$ \\
Mazowia & $13.7 \pm 0.1^{\mathrm{a}}$ & $2.48 \pm 0.02^{\mathrm{a}}$ & $3.01 \pm 0.03^{\mathrm{a}}$ \\
Progres & $12.04 \pm 0.2^{\mathrm{c}}$ & $2.07 \pm 0.02^{\mathrm{c}}$ & $2.34 \pm 0.02^{\mathrm{b}}$ \\
Isidor $^{*}$ & $10.3 \pm 0.3^{\mathrm{d}}$ & $1.71 \pm 0.05^{\mathrm{d}}$ & $1.77 \pm 0.02^{\mathrm{e}}$ \\
Satina $^{*}$ & $12.5 \pm 0.1^{\mathrm{b}}$ & $2.06 \pm 0.02^{\mathrm{c}}$ & $2.16 \pm 0.02^{\mathrm{d}}$ \\
\hline
\end{tabular}

Means with the different letters $(\mathrm{a}, \mathrm{b}, \mathrm{c}, \mathrm{d}, \mathrm{e})$ in the column are significantly different $(p<0.05)$. Data represent the mean \pm SD of four replicates Varieties from France are marked with an asterisk $(*)$, the other varieties come from Poland.

\subsection{Scavening Activity and Reducing Power of Extracts}

The capability of prepared extracts from different soybean seed types to scavenge free radicals was determined by in vitro assays using two types of radicals: $\mathrm{DPPH}^{\bullet}$ and $\mathrm{ABTS}{ }^{\bullet+}$. The extracts from all soybean cultivars demonstrated the capability to scavenge both of these free-radical species. The capability of extracts to scavenge $\mathrm{DPPH}^{\bullet}$ is depicted in Figure 1A. Samples possessing the greatest antioxidant power were characterized by the lowest absorbance reading at $517 \mathrm{~nm}$ (Figure 1A). Considerable free-radical scavenging activity, at the highest extract concentration tested, was observed by extracts from seeds of the following varieties: Aldana $\left(A_{517}-0.62\right)$, Mazowia $\left(A_{517}-0.67\right)$, Progres $\left(A_{517}-0.68\right)$, Satina $\left(A_{517}-0.70\right)$, and Isidor $\left(A_{517}-0.73\right)$. The weakest free-radical scavenging capacity was identified in the extract from seeds of $c v$. Augusta $\left(A_{517}-0.74\right)$. The capability of soybean extracts to scavenge $\mathrm{DPPH}^{\bullet}$ is expressed in half maximal effective concentrations (i.e., $\mathrm{EC}_{50}$ values), and the results are displayed in Figure 1B. Superior radical scavenging capacity is denoted by smaller $\mathrm{EC}_{50}$ values. The best $\mathrm{EC}_{50}$ value was observed in extracts from the variety Aldana $(45.9 \mathrm{mg}$ of extract $/ \mathrm{mL})$. $\mathrm{EC}_{50}$ values of other extracts were as follows: Mazowia (50.2 mg of extract $/ \mathrm{mL}$ ), Progres (55.3 mg of extract $/ \mathrm{mL}$ ), and the French variety Satina $(56.1 \mathrm{mg}$ of extract $/ \mathrm{mL})$. The weakest $\mathrm{EC}_{50}$ values were noted in extracts from seeds of the French variety Isidor $(58.7 \mathrm{mg}$ of extract $/ \mathrm{mL}$ ) and Polish variety Augusta (59.5 mg of extract $/ \mathrm{mL})$.

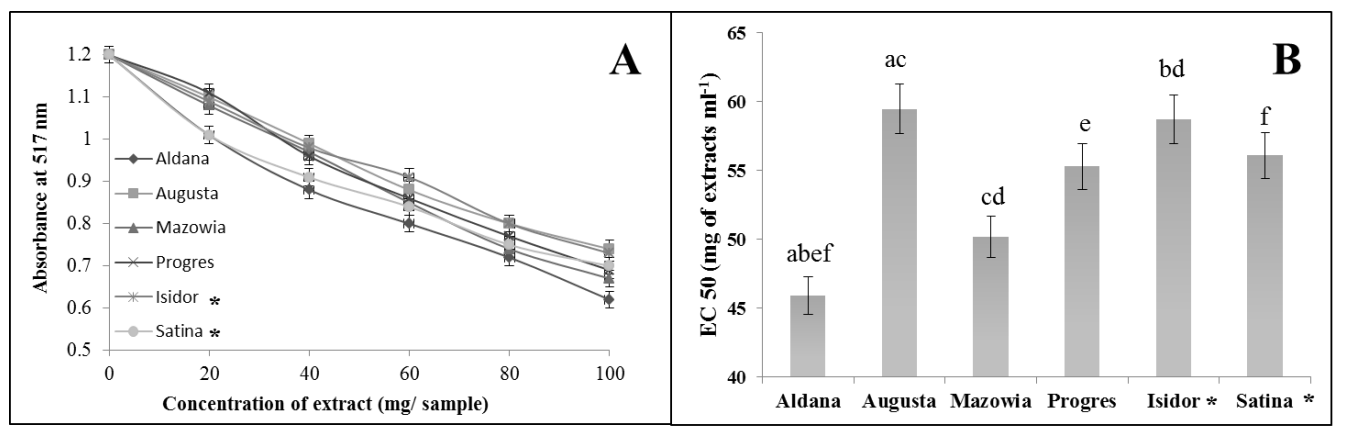

Figure 1. The capability to scavenge the free radical $\mathrm{DPPH}^{\bullet}$ by extracts from soybean seeds (A). Half-maximal effective concentration $\left(\mathrm{EC}_{50}\right)$ of extracts from soybean seeds to scavenge $\mathrm{DPPH}^{\bullet}(\mathbf{B})$. Means with the same letters $(\mathrm{a}, \mathrm{b}, \mathrm{c}, \mathrm{d}, \mathrm{e}, \mathrm{f})$ are not significantly different $(p<0.05)$. Data represent the mean \pm SD of four replicates. Varieties from France are marked with an asterisk $\left(^{*}\right)$, while the other varieties come from Poland.

Seeds extracts for most of the analyzed cultivars exhibited a similar propensity to scavenge ABTS ${ }^{\bullet+}$ (Table 2). Extracts prepared from seeds of the Polish cultivars Progres and Mazowia (50.6 and $50.0 \mu \mathrm{mol}$ Trolox/g of extract, respectively) demonstrated the best capacity at quenching ABTS ${ }^{\bullet+}$. Lower values were obtained for the following cultivars: Satina, Augusta, and Aldana (48.1, 46.2, and $45.4 \mu \mathrm{mol}$ Trolox/g of extract, respectively). The lowest antioxidant capacity of seed extracts was determined for 
the French cultivar Isidor $(44.1 \mu \mathrm{mol}$ Trolox/g of extract). The reducing power of extracts obtained from seeds of different soybean cultivars was determined according to their capability to reduce trivalent iron ions $\left(\mathrm{Fe}^{3+}\right)$ to divalent ones $\left(\mathrm{Fe}^{2+}\right)$ - this was monitored via the ferric reducing antioxidant power (FRAP) assay. The results of these experiments are given in Table 2. Seed extracts from all analyzed soybean cultivars were able to reduce $\mathrm{Fe}^{3+}$. The greatest capacity to do so was observed in extracts from seeds of the cultivar Progres $-104.8 \mu \mathrm{mol} \mathrm{Fe} \mathrm{F}^{2+} / \mathrm{g}$ of extract. A weaker reducing power was determined in extracts from seeds of the following cultivars: Satina, Augusta, and Aldana (96.8, 94.7, and $92.2 \mu \mathrm{mol} \mathrm{Fe} \mathrm{F}^{2+} / \mathrm{g}$ of extract, respectively). Extracts from seeds of cv. Mazowia $(91.2 \mu \mathrm{mol} \mathrm{Fe} / \mathrm{g} \mathrm{of}$ extract) and Isidor $\left(90.3 \mu \mathrm{mol} \mathrm{Fe} \mathrm{F}^{2+} / \mathrm{g}\right.$ of extract) exhibited the lowest reducing power of all soybean seed extracts tested.

Table 2. Trolox equivalent antioxidant capacity (TEAC) and ferric-reducing antioxidant power (FRAP) in soybean seed extracts.

\begin{tabular}{ccc}
\hline \multirow{2}{*}{ Variety } & TEAC & FRAP \\
\cline { 2 - 3 } & $\boldsymbol{\mu}$ mol Trolox/g of Extract & $\boldsymbol{\mu m o l ~ F e}^{\mathbf{2 +}} / \mathbf{g}$ of Extract \\
\hline Aldana & $45.4 \pm 0.3^{\mathrm{c}, \mathrm{d}, \mathrm{e}}$ & $92.2 \pm 6.7^{\mathrm{a}, \mathrm{b}}$ \\
Augusta & $46.2 \pm 1.1^{\mathrm{d}}$ & $94.7 \pm 6.4^{\mathrm{a}, \mathrm{b}}$ \\
Mazowia & $50.0 \pm 0.3^{\mathrm{bc}}$ & $91.2 \pm 4.1^{\mathrm{b}}$ \\
Progres & $50.6 \pm 0.2^{\mathrm{a}}$ & $104.8 \pm 4.8^{\mathrm{a}}$ \\
Isidor $^{\mathrm{e}}$ & $44.1 \pm 0.4^{\mathrm{e}, \mathrm{d}}$ & $90.3 \pm 5.6^{\mathrm{b}}$ \\
Satina $^{*}$ & $48.1 \pm 1.4^{\mathrm{c}}$ & $96.8 \pm 4.8^{\mathrm{a}}$ \\
\hline
\end{tabular}

Means with the different letters $(\mathrm{a}, \mathrm{b}, \mathrm{c}, \mathrm{d}, \mathrm{e})$ in the column are significantly different $(p<0.05)$. Data represent the mean \pm SD of four replicates. Varieties from France are marked with an asterisk $\left.{ }^{*}\right)$, the other varieties come from Poland.

\subsection{Isoflavones Composition}

Separation of the phenolic compounds in the seed extracts from the six soybean cultivars was achieved by reversed-phase high performance liquid chromatography (RP-HPLC). This procedure enabled us to identify the main phenolic compounds, which were found to be isoflavones. Figure 2 illustrates a typical chromatogram for the separation of the isoflavones in one of the soybean extracts, with retention times and absorbances for identified compounds. The following compounds were chromatographed and elucidated: daidzein, genistein, malonyldaidzein, malonylgenistein, daidzin, and genistin.

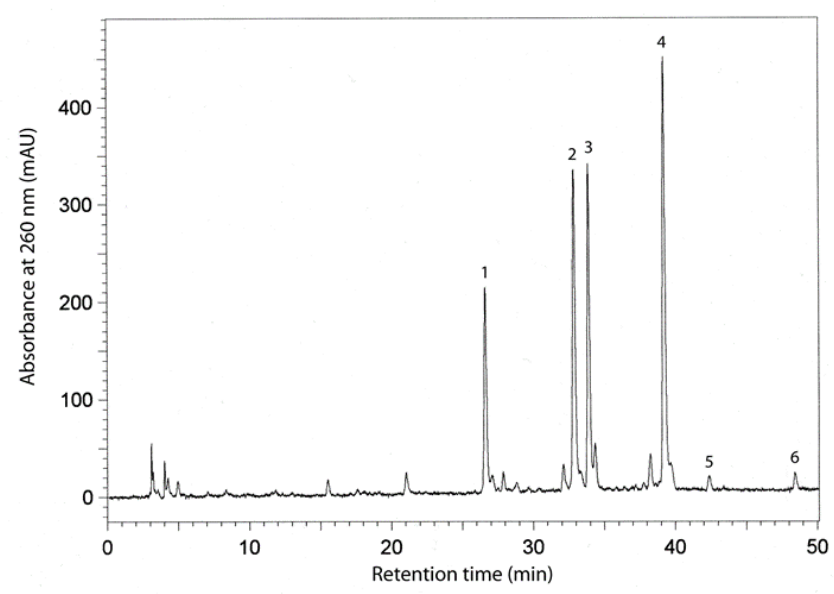

Figure 2. Chromatogram of resolved isoflavones in seed extracts of the soybean cultivar Aldana. The retention times of identified compounds were as follows: 1-daidzein-26 min; 2-genistein-33 min; 3-malonyldaidzein-34 min; 4-malonylgenistein-39 min; 5-daidzin-42 min; and 6-genistin-48 min. 
LC-QTOF analyses confirmed that malonyldaidzein and malonylgenistein were present in all analyzed extracts. The concentrations of isoflavones in seed extracts from the six investigated soybean cultivars are given in Table 3. Marked quantities of daidzein were detected in seed extracts from the cultivars: Mazowia, Progres, Satina, and Augusta (3.03, 2.66, 2.51, and $2.33 \mathrm{mg} / \mathrm{g}$ of extract, respectively), whereas significantly lower quantities of daidzein were determined in seed extracts from the cultivars: Aldana $(2.44 \mathrm{mg} / \mathrm{g}$ of extract) and Isidor $(1.73 \mathrm{mg} / \mathrm{g}$ extract). Considerable and similar amounts of genistein were determined in seed extracts from the cultivars: Progres, Mazowia, Augusta, and Satina $(4.48,4.3,3.72$, and $3.6 \mathrm{mg} / \mathrm{g}$ of extract), whereas markedly less of this isoflavone was detected in seed extracts from the soybean cultivars: Aldana $(3.33 \mathrm{mg} / \mathrm{g}$ of extract) and Isidor $(2.68 \mathrm{mg} / \mathrm{g}$ of extract). Another identified isoflavone derivative was malonyldaidzein: it occurred in large and similar concentrations in extracts from seeds of the following soybean cultivars: Mazowia, Aldana, Progres, Satina, Augusta (6.30, 5.90, 5.41, 5.23, and $5.15 \mathrm{mg} / \mathrm{g}$ of extract, respectively). On the other hand, less of this particular isoflavone was determined in the seed extract from $\mathrm{cv}$. Isidor $(3.83 \mathrm{mg} / \mathrm{g}$ of extract). The compound that appeared in the highest concentration in all analyzed samples was malonylgenistein. It occurred in similar concentrations in soybean seed extracts from the varieties: Augusta, Progres, Mazowia, Aldana and Satina (7.96, 7.28, 7.23, 7.04, and $6.52 \mathrm{mg} / \mathrm{g}$ of extract). Markedly less malonylgenistein was found in extracts from seeds of $\mathrm{cv}$. Isidor ( $5.81 \mathrm{mg} / \mathrm{g}$ of extract). Another analyzed compound, daidzin, was detected in substantial concentrations in seed extracts from cv. Satina ( $0.3 \mathrm{mg} / \mathrm{g}$ of extract). In contrast, it was detected in markedly lower levels in extracts from seeds of the cultivars: Mazowia, Augusta, Progres, Aldana, and Isidor $(0.21,0.19,0.19,0.18$, and $0.16 \mathrm{mg} / \mathrm{g}$ of extract). One final identifiable isoflavone was chromatographed, namely geistin. Its high and similar content was detected in extracts from seeds of the cultivars: Satina, Progres, and Mazowia $\left(0.26,0.25,0.2 \mathrm{mg} \mathrm{g}^{-1}\right.$ of extract, respectively). Markedly less genistin was found in soybean seed extracts from the cultivars Aldana, Augusta, and Isidor $(0.18,0.17$ and $0.1 \mathrm{mg} / \mathrm{g}$ of extract). Finally, it should be mentioned that a high and comparable total content of isoflavones was characteristic for seed extracts from the cultivars Mazowia, Progres, Augusta, Aldana, and Isidor (21.3, 20.27, 19.52, 18.87 , and $18.42 \mathrm{mg} / \mathrm{g}$ of extract). Conversely, a lower total content of isoflavones was determined in extracts from soybean seeds of $\mathrm{cv}$. Isidor (14.31 mg/g of extract).

Table 3. Content of isoflavones in extracts from soybean seeds.

\begin{tabular}{|c|c|c|c|c|c|c|c|}
\hline Variety & \multicolumn{7}{|c|}{ Isoflavones (mg/g-of Extract) } \\
\hline Aldana & $2.24 \pm 0.13^{\mathrm{d}}$ & $3.33 \pm 0.19^{c}$ & $5.91 \pm 0.34^{\mathrm{a}, \mathrm{b}}$ & $7.04 \pm 0.44^{\mathrm{a}}$ & $0.18 \pm 0.03^{b}$ & $0.18 \pm 0.02^{c}$ & $18.87 \pm 2.23^{\mathrm{a}, \mathrm{b}}$ \\
\hline Mazowia & $3.05 \pm 0.16^{\mathrm{a}}$ & $4.31 \pm 0.31^{\mathrm{a}, \mathrm{b}}$ & $6.33 \pm 0.34^{\mathrm{a}}$ & $7.23 \pm 0.89^{b}$ & $0.21 \pm 0.02^{b}$ & $0.21 \pm 0.01^{b, c}$ & $21.3 \pm 1.74^{\mathrm{a}}$ \\
\hline Progres & $2.66 \pm 0.14^{b}$ & $4.48 \pm 0.33^{\mathrm{a}}$ & $5.41 \pm 0.53^{c}$ & $7.28 \pm 1.03^{b}$ & $0.19 \pm 0.02^{b, c}$ & $0.25 \pm 0.03^{b}$ & $20.27 \pm 1.59^{a, b}$ \\
\hline Isidor * & $1.73 \pm 0.05^{\mathrm{e}}$ & $2.68 \pm 0.14^{\mathrm{d}}$ & $3.83 \pm 0.39^{d}$ & $5.81 \pm 0.12^{b}$ & $0.16 \pm 0.01^{c}$ & $0.11 \pm 0.01 \mathrm{~d}$ & $14.31 \pm 1.14^{c}$ \\
\hline
\end{tabular}

Means with different letters $(\mathrm{a}, \mathrm{b}, \mathrm{c}, \mathrm{d}, \mathrm{e})$ in the column are significantly different $(p<0.05)$. Data represent the mean \pm SD of three replicates. Varieties from France are marked with an asterisk $\left(^{*}\right)$, the other varieties come from Poland.

\section{Discussion}

Soybeans are grown mostly in the USA, Brazil, China, and India. This pattern of global distribution is mainly dictated by the high thermal and soil requirements of this plant [22,23]. Under northern Europe conditions, soybean seeds are often sown in chilled soil, and during spring, the emerging plants are often exposed to short spells of cold. This is the main cause for the plant's uneven emergence, seed setting, delayed flowering, and often low yields [24]. The Polish register of crops, COBOR, contains eight soybean cultivars, namely Aldana, Augusta, Jutro, Mazowia, Nowiko, Progres, Pripyat, and Yanina. Of the varieties compared herein, it was only cv. Aldana that yielded above the average (104\% of the model), whereas Augusta and Nowiko achieved $98 \%$ and $96 \%$ of the model yield. Regarding the other cultivars, there are no comparative data available to discuss their yields [25]. Kozak et al. [26] 
verified that the main determinants of seed yield are the minimum air temperature, amplitude of temperatures, and mean daily air temperature.

The main purpose of this study was to compare the quantities and composition of phenolic compounds in seeds of Polish and foreign (i.e., French) soybean cultivars. It is rather uncertain what factors regulate the production and distribution of phenolic compounds in soybean seeds. It is believed that an elevated level of phenolics in seeds protects them better from the harmful impact of both biotic and abiotic stresses. It is also claimed that these compounds can bestow beneficial effects on the human health. The present study found that the content of phenolic compounds in soybean seeds from most of the Polish cultivars analyzed (Aldana, Mazowia, and Progres) was higher than those in the French varieties (Isidor and Satina), thereby possibly indicating an important role of phenolic compounds in the adaptation of Polish cultivars to the local climatic conditions. Seeds of the Polish cultivar Augusta possessed a much lower content of phenolic compounds than any of the other Polish varieties. In fact, similar to the levels detected in the French cultivars. Furthermore, it was noted that this cultivar was characterized by a low yield based on the climatic conditions of Poland [25]. Phenolic extracts from these seeds were also distinguished by a low free-radical scavenging capacity.

Prakash et al. [27] analyzed 30 soybean cultivars from India, of which the highest content of phenolic compounds was determined for cv. Kalitur, whose seeds are black. In another study, it was shown that the phenolic compounds were partitioned differently between the top and bottom seed nodes [28]. Another finding indicated that the average TPC in green soybean sprouts was higher than in yellow counterparts when grown under dark conditions [29]. Other researchers have noted that phenolic metabolism in germinating soybean seeds is much more intensive in response to low temperature and osmotic stress, and remains at a high level during recovery after this stress [30]. Under stress conditions, the amount and composition of identified phenolic acids and isoflavones changes. This indicates the important role of phenolic compounds in alleviating the effects of abiotic stress during the germination of soybean seeds, and offers new perspectives for further investigation. Of particular note are phytoalexins, which are synthesized intensively when a plant is invaded by fungi following a bacterial or viral infection. Pisatin is the most thoroughly investigated phenolic phytoalexin. It is an isoflavonoid synthesized in pea pods after an infection with brown-rot fungus. The latest proteomic research has shown that 6a-hydroxymaackian-3-O-methyltransferase, which is involved in the synthesis of pisatin, was present, but only under osmotic stress conditions, thereby denoting its key role in the acquisition of stress tolerance by plants [31]. The identified protein, 6a-hydroxymaackian methyltransferase, can serve as an object for an engineering strategy, involved in certain new plant varieties that will be more resistant to unfavorable environmental conditions.

Isoflavones, a class of flavonoid in soybean seeds, have been found to possess important secondary compounds with many chemical actions. Especially useful seems to be their antioxidant and anticancer actions [29]. Numerous studies have demonstrated a correlation between isoflavone contents and the soybeans cultivation environment [28,32,33].

The soybean phenolic extracts analyzed in this study by RP-HPLC contained the following six isoflavonoids: daidzein, genistein, daidzin, genistin, malonyldadzein, and malonylgenistein. These are the major soybean flavonoids, as has been reported by numerous researchers [4,33-37]. These isoflavonoids were detected in high concentrations in the seed extracts, and ranged from 14.31 to $21.3 \mathrm{mg} / \mathrm{g}$ of extract. This study indicates that, despite differences in quantities of individual compounds in the various seed extracts, only extracts from the seeds of the French cultivar Isidor were characterized by a significantly lower total content of isoflavones than any others. The total content of isoflavones in seed extracts from all analyzed cultivars here is within the range of the levels determined for seeds of different soybean cultivars [13,32,38,39]. According to Seo and Morr [40], the content of isoflavonoids constitutes about $72 \%$ of all phenolic compounds in soybean seeds. Isoflavones are very powerful antioxidants, especially those occurring in their free form, such as genistein and dadzein, which possess the highest antioxidant power of all isoflavones in foodstuffs [33]. Depending on the 
quantity and composition of isoflavones, different types of soybean and soybean products demonstrate varied antioxidant activity [41].

The research findings reported in this paper show that seed extracts from the analyzed soybean varieties have a high capacity to reduce the DPPH radical and the ABTS radical cation. The weakest power to scavenge free radicals was observed for $\mathrm{cv}$. Augusta, while the other cultivars, namely Aldana, Mazowia, Progres, Isidor, and Satina, demonstrated a similar or greater scavenging power. Seed phenolic extracts from the aforementioned cultivars from India are highly varied in their capacity to scavenge free radicals. Analogous to our investigation, a correlation was determined between the content of phenolic compounds and their capability to scavenge free radicals by extracts prepared from these seeds [26]. Malencic et al. [42] also demonstrated a linear dependence between the content of phenolic compounds in seeds and the capacity of extracts isolated from these seeds to scavenge free radicals.

\section{Materials and Methods}

\subsection{Chemicals}

Folin-Ciocalteu's phenol reagent (FCR), (+)-catechin, sodium carbonate, gallic acid, 2,2'-diphenyl-1-picrylhydrazyl (DPPH), 2,2'-azinobis-(3-ethylbenzothiazoline-6-sulfonic acid) (ABTS), 2,4,6-tri(2-pyridyl)-S-triazine (TPTZ), 6-hydroxy-2,5,7,8-tetramethyl-chroman-2-carboxylic acid (Trolox), trifluoroaceitc acid, daidzein, genistein, malonyldaidzein, malonylgenistein, daidzin, and genistin were obtained from the Sigma-Aldrich Chemical Company (St. Louis, MO, USA). Methanol, acetone, hexane, acetonitrile, acetic acid, ferric chloride, and potassium persulfate were acquired from Chempur (Piekary Ślaskie, Poland).

\subsection{Plant Material}

The biological material used in these experiments comprised seeds of six cultivars of common soybeans (Glycine max L.), four Polish cultivars, namely Aldana, Augusta, Mazowia, and Progres, and two French ones, namely Isidor and Satina. The Polish cultivars originated from the Central Research Station on Crop Cultivars in Słupia Wielka, while the French ones were supplied by Actisem (le Jardin, Francescas, France). The dry matter of seeds was determined by drying at $105^{\circ} \mathrm{C}$ for $24 \mathrm{~h}$.

\subsection{Phenolic Compounds Extraction}

Seeds from six varieties of soybeans were ground in a coffee mill and defatted with hexanes using a Soxhlet apparatus for 6-8 h. Phenolic compounds were extracted from the defatted raw seeds with $80 \%(v / v)$ acetone and $80 \%(v / v)$ methanol at a solids-to-solvent ratio of $1: 10(w / v)$ at $50{ }^{\circ} \mathrm{C}$ for $30 \mathrm{~min}$ [43]. The extraction was carried out in glass bottles in a shaking water bath (Elpan 357, Wrocław, Poland). The extraction was repeated two more times, the supernatants were filtered and combined. The organic solvent was then evaporated under vacuum using a Büchi rotary evaporator (Flawil, Switzerland) and water bath set at $40{ }^{\circ} \mathrm{C}$. The resultant aqueous solutions was frozen and lyophilized.

\subsection{Total Phenolics Content (TPC)}

The TPC in extracts was determined using Folin-Ciocalteu's phenol reagent (FCR), Sigma-Aldrich Chemical Company (St. Louis, MO, USA) [44]. To $0.25 \mathrm{~mL}$ of a methanolic solution of phenolic extract (containing between 0.1 to $0.2 \mathrm{mg}$ of extract) was added $0.25 \mathrm{~mL}$ of a saturated sodium carbonate solution, $0.25 \mathrm{~mL}$ Folin-Ciocalteu's phenol reagent, and $4 \mathrm{~mL}$ of deionized water. The mixture was vortexed and then incubated at room temperature in dark for $0.5 \mathrm{~h}$. After this period, the absorbance was read at $725 \mathrm{~nm}$ using a spectrophotometer. (+)-Catechin was employed as the standard. 


\subsection{Scavenging of the DPPH Radical}

The scavenging effect of phenolic compounds from the extracts was measured accordance to Yen and Chen [45]. Briefly, $0.1 \mathrm{~mL}$ of a methanolic solution of phenolic extract (containing 0.05 to $0.1 \mathrm{mg}$ of extract) was mixed with $2 \mathrm{~mL}$ of deionized water, to which a freshly prepared methanolic solution of $\mathrm{DPPH}^{\bullet}(1 \mathrm{mM}, 0.25 \mathrm{~mL})$, Sigma-Aldrich Chemical Company (St. Louis, MO, USA) was then added. The mixture was vortexed and incubated at room temperature for $20 \mathrm{~min}$. The absorbance was read at $517 \mathrm{~nm}$ using a spectrophotometer. The results were presented as half maximal effective concentrations to quench the $\mathrm{DPPH}^{\bullet}\left(\mathrm{EC}_{50}\right)$ in units of $\mathrm{mg}$ of extract $/ \mathrm{mL}$.

\subsection{Trolox Equivalent Antioxidant Capacity (TEAC)}

The TEAC assay was carried out in accordance with Huang et al. [46]. Briefly, $0.1 \mathrm{~mL}$ of a methanolic solution of phenolic extract (containing 0.1 to $0.5 \mathrm{mg}$ of extract) was added to $0.1 \mathrm{~mL}$ of methanol (Chempur (Piekary Ślaskie, Poland)) and $2 \mathrm{~mL}$ of ABTS $^{\bullet+}$ (Sigma-Aldrich Chemical Company (St. Louis, MO, USA)). The mixture was vortexed and incubated in the dark at $32{ }^{\circ} \mathrm{C}$ for $20 \mathrm{~min}$. The absorbance was read at $734 \mathrm{~nm}$ using a spectrophotometer. A calibration curve was prepared using Trolox (Sigma-Aldrich Chemical Company (St. Louis, MO, USA)) as the standard. Results were reported as $\mu \mathrm{mol}$ Trolox equivalents/g of extract.

\subsection{Ferric-Reducing Antioxidant Power}

Reducing powers of the phenolic extracts were determined using the FRAP assay [47]. Briefly, 0.1 to $0.5 \mathrm{mg}$ of phenolic extract was dissolved in $0.1 \mathrm{~mL}$ of deionized water, to which $3 \mathrm{~mL}$ of freshly prepared FRAP reagent (acetic acid buffer of pH 3.6 TPTZ (2,4,6-tris(2-pyridyl)-S-triazine) was added. The mixture was incubated for $30 \mathrm{~min}$ at ambient temperature. After incubation, the absorbance was read at $593 \mathrm{~nm}$. The results were expressed as $\mu \mathrm{mol} \mathrm{Fe} e^{2+} / \mathrm{g}$ of extract.

\subsection{Isoflavones Analysis}

An RP-HPLC Shimadzu system (Shimadzu, Kyoto, Japan) was used to analyze the isoflavones in the extracts from the soybean seeds. The phenolic extracts were dissolved in $80 \%(v / v)$ methanol and passed through a $0.45 \mu \mathrm{m}$ nylon filter prior to injection [48]. The separation was carried out using a gradient elution. The A solvent consisted of a mixture of water, acetonitrile, and trifluoroaciteic acid (95:5:1 v:v:v), while the B solvent comprised acetonitrile and trifluoroaceitc acid (Chempur (Piekary Ślaskie, Poland, 100:1 v:v)). The flow of solvent B in the linear gradient was from $0 \%$ to $40 \%$ over $60 \mathrm{~min}$. The analysis of each phenolic extract was performed in triplicate. Linearity of the detector responses was determined for daidzin and genistein (range of 0.05 to $0.15 \mathrm{mg} / \mathrm{mL}$ ), daidzein (range of 0.01 to $0.04 \mathrm{mg} / \mathrm{mL}$ ), and genistin (range of 0.02 to $0.08 \mathrm{mg} / \mathrm{mL}$ ). The relation between area under a peak and standard concentrations was characterized by a correlation coefficient of 0.997 for genistein, and 0.998 for daidzin, daidzein, and genistein.

Next, the analysis of soybean isoflavones were continued using a micro-HPLC system (LC200, Eksigent, Framingham, MA, USA) consisting of a dual-channel pump, column oven, autosampler, and system controller. The micro-HPLC was coupled to a 5600 QTOF mass spectrometer (SCIEX, Ontario, Canada). Five $\mu \mathrm{L}$ of each sample were injected onto the chromatography column, HALO C18, $2.7 \mu \mathrm{m}$, $0.5 \times 50 \mathrm{~mm}$ (Eksigent, Framingham, MA, USA). All chromatographic determinations were performed at $45^{\circ} \mathrm{C}$, at a mobile phase flow rate of $15 \mu \mathrm{L} / \mathrm{min}$, using the following gradient: $5-5-90-90-5-5 \% \mathrm{~B}$ in 0-0.5-1.8-2.8-3-5 $\min$ (phase A: water/formic acid, 99.1/0.9 (v/v) phase B: acetonitrile/formic acid, $99.1 / 0.9(v / v))$.

QTOF conditions in the negative-ion mode were as follows: nitrogen curtain gas, $25 \mathrm{~L} / \mathrm{min}$; ion-spray source voltage, $-4500 \mathrm{~V}$ NEG; temperature, $350{ }^{\circ} \mathrm{C}$; nebulizer gas $1,35 \mathrm{~L} / \mathrm{min}$; turbo gas, $30 \mathrm{~L} / \mathrm{min}$; Q1/Q2, DP -90/-80 V; CE -10/-10 V (CE10/30); and CES $15 \mathrm{~V}$. 
QTOF conditions in the positive-ion mode were as follows: nitrogen curtain gas, $25 \mathrm{~L} / \mathrm{min}$; ion-spray source voltage, $5500 \mathrm{~V}$ POS; temperature, $350{ }^{\circ} \mathrm{C}$; nebulizer gas $1,35 \mathrm{~L} / \mathrm{min}$; turbo gas, $30 \mathrm{~L} / \mathrm{min} ; \mathrm{Q} 1 / \mathrm{Q} 2, \mathrm{DP}$ 90/80 V; CE 10/10 V (CE10/30); and CES $15 \mathrm{~V}$.

\subsection{Statistical Analysis}

Antioxidant assays and HPLC separations and identification of isoflavones were performed for at least three repetitions. All results were presented as means \pm standard deviations (SD). Significance of differences among mean values were analyzed using a nonparametric test (Friedman and Wilcoxon test) at a level of $p<0.05$ in software Statistica.

\section{Conclusions}

The research presented in this paper has demonstrated that the total content of phenolic compounds and antioxidant capacities in extracts of soybean seeds for most of the examined Polish cultivars was higher than those of the French varieties. Thus, it can be concluded that it is the phenolic compounds enclosed in seed extracts that are mostly responsible for the free-radical scavenging capacity in soybean seeds. Isoflavones were determined in all investigated soybean extracts: genistein, daidzein, malonyl daidzein, malonyl genistein, and daidzin were detected. Noteworthy is that the factors regulating the production of phenolic compounds in seeds have not been thoroughly recognized in literature. Consequently, many teams of researchers conduct experiments in order to select soybean seeds with higher levels of seed phenolics, because of their beneficial impact on human health and on soybean's defense mechanism against both biotic and abiotic stresses.

Author Contributions: Conceptualization, A.K.-G. and R.A.; methodology, R.A.; software and validation, A.K.-G.; formal analysis, A.K.-G. and R.A.; investigation, A.K.-G. and R.A.; writing-original draft preparation, A.K.-G.; supervision, R.A. All authors have read and agreed to the published version of the manuscript.

Funding: This research received no external funding.

Conflicts of Interest: The authors declare no conflict of interest.

\section{References}

1. Dixon, R.A.; Summer, L.W. Legume natural products: Understanding and manipulating complex pathways for human and animal health. Plant Physiol. 2003, 131, 878-885. [CrossRef] [PubMed]

2. Muchaweity, M.; Ndhlala, A.R.; Ksiamhuru, A. Analysis of phenolic compounds including tannins, gallotannins and flavanols of Uapaca kirkiana fruit. Food Chem. 2006, 94, 415-419. [CrossRef]

3. Deng, J.; Qin, W.; Yang, C.; Iqbal, N.; Takpah, D.; Zhang, J.; Yang, W.; Liu, J. Seed quality deterioration dynamics for isoflavones biosynthesis in soybean (Glycine max L. Merr.) seeds against field mildew stress. Acta Physiol. Plant. 2019. [CrossRef]

4. Kalaiselvan, V.; Kalaivani, M.; Vijayakumar, A.; Sureshkumar, K.; Venkateskumar, K. Current knowledge and future direction of research on soy isoflavones as a therapeutic agents. Pharmacogn. Rev. 2010, 4, 111-117. [CrossRef] [PubMed]

5. Sharma, A.; Shahzad, B.; Rehman, A.; Bhardwaj, R.; Landi, M.; Zheng, B. Response of phenylpropanoid pathway and the role of polyphenols in plants under abiotic stress. Molecules 2019, 24, 2452. [CrossRef]

6. Carrera, C.S.; Dardanelli, J.L. Changes in the relationship between temperature during the seed-filling period and soya bean seed isoflavones under water-deficit conditions. J. Agron. Crop Sci. 2016, 202, 421-432. [CrossRef]

7. Villegas, R.; Gao, Y.T.; Yang, G.; Li, H.L.; Elasy, T.A.; Zheng, W. Legume and soy food intake and the incidence of type 2 diabetes in the Shanghai Women's Health study. Am. J. Clin. Nutr. 2008, 87, 162-167. [CrossRef]

8. Santell, R.C.; Kieu, N.; Helferich, W.G. Genistein Inhibits Growth of Estrogen-Independent Human Breast Cancer Cells in Culture but Not in Athymic Mice. J. Nutr. 2000, 130, 1665-1669. [CrossRef]

9. Rivero, R.M.; Ruiz, J.M.; Garcia, P.C.; Lopez-Lefebre, L.R.; Sanchez, E.; Romero, L. Resistance to cold and heat stress: Accumulation of phenolic compounds in tomato and watermelon plants. Plant Sci. 2001, 160, 315-321. [CrossRef] 
10. Dixon, R.A.; Achnine, L.; Kota, P.; Liu, C.J.; Srinivasa, M.S.; Wang, L. The phenylpropanoid pathway and plant defence a genomics perspective. Mol. Plant Pathol. 2002, 3, 371-390. [CrossRef]

11. Król, A.; Amarowicz, R.; Weidner, S. Changes in the composition of phenolic compound and antioxidant properties of grapevine roots and leaves (Vitis vinifera L.) under continuous of long-term drought stress. Acta Physiol. Plant. 2014, 36, 1491-1499. [CrossRef]

12. Król, A.; Amarowicz, R.; Weidner, S. The effects of cold stress on the phenolic compounds and antioxidant capacity of grapevine (Vitis vinifera L.) leaves. J. Plant Physiol. 2015, 189, 97-104. [CrossRef]

13. Heim, K.E.; Tagliaferro, A.R.; Boblya, D.J. Flavonoid antioxidants: Chemistry, metabolism and structure-activity relationships. J. Nutr. Biochem. 2002, 13, 572-584. [CrossRef]

14. Filip, V.; Plockova, M.; Smidkral, J.; Spickova, Z.; Melzoch, K.; Schmidt, S. Resveratrol and its antioxidant and antimicrobial effctiveness. Food Chem. 2003, 83, 585-593. [CrossRef]

15. Oh, M.M.; Trick, H.N.; Rajashekar, C.B. Secondary metabolism and antioxidants are involved in environmental adaptation and stress tolerance in lettuce. J. Plant Physiol. 2009, 166, 180-191. [CrossRef]

16. Boscaiu, M.; Sánchez, M.; Bautista, I.; Donat, P.; Lidón, A.; Llinares, J.; Llul, C.; Mayoral, O.; Vicente, O. Phenolic Compounds as Stress Markers in Plants from Gypsum Habitats. Bull. Univ. Agric. Sci. Vet. Med. 2010, 67, 1843-5394.

17. Crouse, J.R.; Morgan, T.; Terry, J.G. A randomized trial comparing the effect of casein with that of soya protein containing varying amounts of isoflavones on plasma concentrations of lipids and lipoproteins. Arch. Intern. Med. 1999, 159, 2070-2076. [CrossRef]

18. Kwak, C.S.; Lee, M.S.; Park, S.C. Higher antioxidant properties of chungkookjang, a fermented soybean paste, may be due to increased aglycone and malonyl glycoside isoflavone during fermentation. Nutr. Res. 2007, 27, 719-727. [CrossRef]

19. Jasińska, Z.; Kotecki, A. Legumes; Wydawnictwo Naukowe PWN: Warsaw, Poland, 1993; pp. $146-167$.

20. Solecka, D. Role of phenylpropanoid compounds in plant to different stress factors. Acta Physiol. Plant. 1997, 19, 257-268. [CrossRef]

21. Franca, S.C.; Roberto, P.G.; Marins, M.A.; Puga, R.D.; Rodriguez, A.; Pereira, J.O. Biosynthesis of secondary metabolites in sugarcane. Gen. Mol. Biol. 2001, 24, 243-250. [CrossRef]

22. FAOAST. Statistical Databases. 2006. Available online: http://faostat.fao.org/ (accessed on 20 December 2019).

23. Prusiński, J.; Kotecki, A. Contemporary the problem of the production of legumes. Fragm. Agron. 2006, 91, 94-126.

24. Borowski, E.; Michałek, S. The effect of chilling temperature on germination and early growth of domestic and Canadian soybean (Glycine max (L.) Merr.) cultivars. Acta Sci. Pol. Hortorum. Cultus. 2014, 13, 31-43.

25. Dolata, A.; Wiatr, K. Leguminous plants (pea, fababean, blue lupine, yellow lupine). Previse results yielding experiments of postregistre varieties. COBORU 2007, 83, 200-205.

26. Kozak, M.; Malarz, W.; Kotecki, A.; Černý, J.; Serafin-Andrzejewska, M. The effect of sowing rate and Asahi biostimulator on chemical composition of soybean seeds and postharvest residues. Oilseed Crops 2008, XXIX, 217-230.

27. Prakash, D.; Upadhyay, G.; Singh, B.N.; Singh, H. Antioxidant and free radical-scavenging activities of seeds and agri-wastes of some varieties of soybean (Glycine max). Food Chem. 2007, 104, 783-790. [CrossRef]

28. Bellaloni, N. Soybean seed phenol, lignin, and isoflavones partitioning as affected by seed node position and genotype differences. Food Nutr. Sci. 2012, 3, 447-454.

29. Kim, E.H.; Kim, S.H.; Chung, J.; Chi, H.Y.; Kim, J.A.; Chung, I.M. Analysis of phenolic compounds and isoflavones in soybean seeds (Glycine max (L.) Merill) and sprouts grown under different conditions. Eur. Food Res. Technol. 2006, 222, 201-208. [CrossRef]

30. Swigonska, S.; Amarowicz, R.; Król, A.; Mostek, A.; Badowiec, A.; Weidner, S. Influence of abiotic stress during soybean germination followed by recovery on the phenolic compounds of radicles and their antioxidant capacity. Acta Soc. Bot. Pol. 2014, 83, 209-218. [CrossRef]

31. Brosowska-Arendt, W.; Gallardo, K.; Sommerer, N.; Weidner, S. Changes in the proteome of pea (Pisum sativum L.) seeds germinating under optimal and osmotic conditions and subjected to post-stress recovery. Acta Physiol. Plant. 2014, 36, 795-807. [CrossRef]

32. Wang, H.J.; Murphy, P.A. Isoflavone content in commercial soybean foods. J. Agric. Food Chem. 1994, 42, 1666-1673. [CrossRef] 
33. Chen, H.C.; Ho, C.T. Antioxidant activities of caffeic acid and its related hydroxycinnamic acid compounds. J. Agric. Food Chem. 1997, 45, 2374-2378. [CrossRef]

34. Lee, J.C.; Kim, H.R.; Kim, J.; Jang, Y.J. Antioxidant property of an ethanol extract of the stem of Opuntiaficus-indicavar Saboten. J. Agric. Food Chem. 2002, 50, 6490-6496. [CrossRef] [PubMed]

35. Akhita Devi, M.K.; Gandhi, M.; Sakthivelu, G.; Girdihar, P.; Rajasekaran, T.; Ravishankar, G.A. Functional attributes of soybean seeds and products, with reference to isoflavone content and antioxidant activity. Food Chem. 2009, 114, 771-776. [CrossRef]

36. Cho, K.M.; Lee, J.H.; Yun, H.; Ahn, B.Y.; Kim, H.; Seo, W.T. Changes of phytochemical constituents (isoflavones, flavanols, and phenolic acids) during cheonggukjang soybeans fermentation using potential probiotics Bacillus subtilis CS90. J. Food Comp. Anal. 2011, 24, 402-410. [CrossRef]

37. Lee, J.H.; Lee, B.W.; Kim, B.; Kim, H.T.; Ko, J.M.; Baek, I.; Seo, T.W.; Kang, Y.M.; Cho, K.M. Changes in phenolic compounds (isoflavones and phenolic acids) and antioxidant properties in high-protein soybean (Glycine max L., cv. Saedanbaek) for different roasting conditions. J. Korean Soc. Appl. Biol. Chem. 2013, 56, 605-612. [CrossRef]

38. Carrão-Panizzi, M.C.; Kitamura, K. Isoflavone content in brazilian soybean cultivars. Breed. Sci. 1995, 45, 295-300.

39. Tsukamoto, C.; Shimada, S.; Igita, K.; Kudou, S.; Kokubun, M.; Okubo, K.; Kitamura, K. Factors affecting isoflavone content in soybean seeds: Changes in isoflavones, saponins composition of fatty acids at different temperatures during the seeds development. J. Agric. Food Chem. 1995, 43, 1184-1192. [CrossRef]

40. Seo, A.; Morr, C.V. Improved high performance liquid chromatographic analysis of phenolic acids and isoflavonoids from soybean protein products. J. Agric. Food Chem. 1984, 32, 530-533. [CrossRef]

41. Lee, C.H.; Yang, L.; Xu, J.Z.; Yeung, S.Y.V.; Huang, Y.; Chen, Z. Relative antioxidant activity of soybean isoflavones and their glycosides. Food Chem. 2005, 90, 735-741. [CrossRef]

42. Malencic, D.; Maksimovic, Z.; Popovic, M.; Miladinovic, J. Polyphenol contents and antioxidant activity of soybean seed extracts. Biores. Technol. 2008, 99, 6688-6691. [CrossRef]

43. Amarowicz, R.; Raab, B. Antioxidative activity of leguminous seed extracts evaluated by chemiluminescence methods. Pol. J. Food Nutr. Sci. 2001, 52, 709-712. [CrossRef]

44. Karamać, M.; Kosińska, A.; Estrella, I.; Hernández, T.; Dueñas, M. Antioxidant activity of phenolic compounds identified in sunflower seeds. Eur. Food Res. Technol. 2012, 235, 221-230. [CrossRef]

45. Yen, G.C.; Chen, H.Y. Antioxidant activity of various tea extracts in relation to their antimutagenicity. J. Agric. Food Chem. 1995, 43, 27-32. [CrossRef]

46. Huang, D.; Ou, B.; Prior, D.L. The chemistry behind antioxidant capacity assays. J. Agric. Food Chem. 2005, 53, 1841-1856. [CrossRef]

47. Benzie, F.F.; Strain, J.J. Ferric Reducing/Antioxidant Power Assay: Direct measure of total antioxidant activity of Biological Fluids and modified version for simultaneous measurement of total antioxidant power and ascorbic acid concentration. Methods Enzymol. 1999, 299, 15-23.

48. Amarowicz, R.; Weidner, S. Content of phenolic acids in rye caryopses determined using DAD-HPLC method. Czech J. Food Sci. 2001, 19, 201-205. [CrossRef]

Sample Availability: Samples of the compounds are available from the authors.

(C) 2020 by the authors. Licensee MDPI, Basel, Switzerland. This article is an open access article distributed under the terms and conditions of the Creative Commons Attribution (CC BY) license (http://creativecommons.org/licenses/by/4.0/). 